\title{
PEMBINAAN TAHFIZH AL-QURAN DI PESANTREN TAHFIZH DAARUL QUR'AN TANGERANG
}

\author{
Yudhi Fachrudin \\ Sekolah Tinggi Agama Islam Binamadani Tangerang \\ Jln MH. Tamrin Komplek Mahkota Mas Blok J No. 37 Cikokol Tanggerang \\ Email:yudhi.f@gmail.com
}

\begin{abstract}
Alquran serves as the principal source of Islamic. Alquran has been kept in its purity and authenticity since descended to end of the worla as granted by God, Allah. As a form of its authenticity, Al Qur'an is easy to be memorized. To learn and memorize Al Qur'an as ones of Islamic Education.Al Qur'an memorizing activity became Islamic tradition, as known there are many institutes or boardings which operate tahfidz/ memorizing of Al Qur'an. Each has uniqueness and characteristic in running their own institute.Amongst those institutes, is Daarul Qur'an Tahfizh Boarding School which led and founded by Ustadz Yusuf Mansur.

Keyword: tahfizh, al-Quran, islamic boarding school

Abstrak: Pembinaan Tahfizh Al-Quran Di Pesantren Tahfizh Daarul Qur'an Tangeran. Alquran berfungsi sebagai sumber pokok ajaran dalam Islam. Alquran terjaga keaslian dan keotentikannya dari awal turun sampai kapan pun, Allah sendiri yang menjaminnya. Bentuk penjagaan Alquran, Allah memudahkan bagi manusia untuk menghafalnya. Mempelajari dan menghafal Alquran merupakan salah satu ajaran Islam. Kegiatan menghafal Alquran menjadi tradisi keislaman. Tersedia banyak lembaga pendidikan Islam yang menyelenggarakan program tahfizh Alquran. Masing-masing memiliki perbedaan dan ciri khas pembinaan yang diselenggarakannya. Satu diantaranya, Pesantren Tahfizh Daarul Qur'an Cipondoh Tangerang. Pesantren yang didirikan oleh Ustadz Yusuf Mansur.
\end{abstract}

Kata Kunci: tahfizh, al-Qur'an, Pesantren 


\section{Pendahuluan}

Salah satu bentuk apresiasi terhadap Alquran bahwa Alquran dari generasi ke generasi selalu dihafal dan terjaga dalam dada para penghafal (huffazh) Alquran. Meskipun Alquran ditulis dalam bahasa Arab tetapi Alquran telah dihafal bukan hanya oleh bangsa Arab tetapi juga oleh bangsa non-Arab ('ajam) seperti Indonesia. Berdasarkan data Koran Republika bahwa jumlah penghafal Alquran di Indonesia mencapai 30 ribu orang. Arab Saudi bahkan hanya memiliki 6.000 orang penghafal Alquran. ${ }^{1}$ Tentu tidak sebanding dengan warga Mesir dimana sebanyak 12,3 juta atau sekitar 18,5 persen dari total 67 juta jiwa penduduk Mesir tercatat sebagai penghafal seluruh kitab suci Alquran yang berjumlah 30 juz. Jumlah ini sebanding dengan perhatian besar dari pemerintah Mesir yang dilaporkan setiap tahun mengalokasikan dana khusus sebesar 25 juta dolar AS (1,2Miliar Pound Mesir) untuk penghargaan bagi penghafal Alquran. ${ }^{2}$ Data ini memastikan Alquran menjadi satu-satunya kitab suci di dunia yang paling banyak jumlah orang yang hafal teks tulisannya di luar kepala.

Alquran yang berbahasa Arab, berisi 30 juz dengan 600 halaman itu telah dimudahkan untuk dihafal oleh siapa pun. Hal ini sebagaimana Allah berfirman dalam Alquran surat al-Hijr ayat 9 dan al-Qamar ayat 17 .

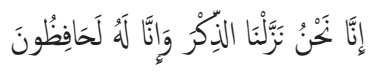

Sesungguhnya Kami-lah yang menurunkan Alquran, dan Sesungguhnya Kami benar-benar memeliharanya. (Qs. al-Hijr 15: 9)

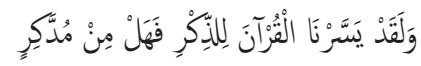

Dan sesungguhnya telah Kami mudahkan Alquran untuk pelajaran, maka adakah orang yang mengambil pelajaran? (Qs. al-Qamar 54:

Sebagian ayat-ayat tentang garansi dari Allah langsung bahwa Alquran akan selalu terjaga. Salah satu realisasinya, Allah memberi kemudahan kepada orang-orang yang ingin menghafal Alquran. Jika ada di kalangan manusia yang berusaha untuk menghafalnya, maka Allah telah mengabarkan bahwa Allah sendiri yang akan memberi

1 Yasmina Hasni, Jumlab Penghafal al Qur'an Indonesia terbanyak di Dunia, sumber http:// www.republika.co.id/berita/dunia-islam/islam-nusantara/10/09/24/136336-jumlah-penghafalalquran-indonesia-terbanyak-di-dunia, diakses pada 11 Oktober 2016

2 ant/dik, 12 Juta warga Mesirhafal al Qur'an,sumberhttp://www.pelita.or.id/ baca.php?id=4515, diakses pada 11 Oktober 2016 
pertolongan dan kemudahan bagi mereka. ${ }^{3}$ Terjaganya Alquran pada hafalan-hafalan umat Islam yang telah mampu menghafal satu Alquran penuh. Ayat ini juga menjadi motivasi bagi siapa saja baik individu maupun suatu lembaga pendidikan dalam menyelenggarakan program menghafal Alquran secara sistematis dan terukur dimana target hafalan Alquran 30 Juz bisa terwujud.

Program menghafal Alquran tidak hanya dikembangkan dan diterapkan di lembaga-lembaga atau pondok-pondok pesantren saja. Program hafalan Alquran telah masuk di lembaga-lembaga pendidikan formal, baik swasta maupun negeri. Oleh karena itu, sekarang banyak ditemukan lembaga pendidikan Islam terpadu yang memiliki program unggulan Tahfizh Alquran. Dengan dinamika masing-masing lembaga pendidikan dalam mengembangkan program pendidikan Tahfizh Alquran di lingkungannya. Pembinaan program tahfizh pada lembaga pendidikan formal memiliki tantangan yang berbeda dibandingkan pada lembaga pendidikan pesantren tahfizh lainnya. Tantangan yang berbeda pula dihadapi antar lembaga pendidikan pesantren dengan pesantren lainnya. Tantangan yang berbeda memunculkan perbedaan dalam perumusan tujuan program tahfizh, latar belakang pembinaan tahfizh, kemampuan sumber daya yang ada, serta ketersedian sarana penunjang lainnya, selanjutnya mempengaruhi pembinaan tahfizh yang diselenggarakannya.

Dengan beragam dinamika dan tantangan yang dihadapi tiap satuan pendidikan dalam menyelenggarakan program tahfizh Alqurannya, hal ini melahirkan beragam model, pola, dan sistem dalam pembinaan program tahfizh Alquran yang diselenggarakannya. Di Indonesia sendiri telah tumbuh subur dan berkembang pesat lembaga-lembaga penyelenggara program pembinaan penghafal Alquran yang mutqin dalam hafalannya. Masing-masing berkembang dengan keunggulan dan ciri khasnya dalam melakukan pembinaan tahfizh Alquran. Satu diantaranya adalah Pesantren Tahfizh Daarul Qur'an yang berada di Tangerang.

Pesantren Tahfizh Daarul Qur'an mengadakan pembinaan tahfizh Alquran secara pendidikan formal dan non formal. Pada pendidikan formal dimulai dari jenjang anak-anak (Playgroup, TK, $\mathrm{SD}$ baik sekolah formal maupun berasrama), pada tingkat remaja

${ }^{3}$ Hasan bin Ahmad bin Hasan Hamam, Menghafal Alquran Itu Mudah Jakarta: At-Tazkia, 2008, h, 13 . 
dilakukan pembinaan tahfizh Alquran dengan sistem pendidikan pondok pesantren sekaligus menyelenggarakan pendidikan formal yaitu jenjang SMP dan SMA di dalamnya. Pada jenjang pendidikan tinggi pembinaan tahfizh berlangsung bagi mahasiswa dan mahasiswi di kampus Sekolah Tinggi Manajemen Informatika dan Komputer (STMIK) Antar Bangsa. Selain melakukan pembinaan tahfizh Alquran bagi anak didik yang belajar, pembinaan tahfizh Alquran pun berlaku bagi para guru-guru tahfizh Alquran di lingkungan Pesantren Tahfizh Daarul Qur'an. Pembinaan Tahfizh Alquran pun telah diselenggarakan guna menyiapkan guru-guru pengajar tahfizh Alquran itu sendiri. Selain itu pula dikembangkan pembinaan tahfizh pada satu tempat yang khusus dan waktu yang telah ditentukan yang dikenal dengan program takhasus Alquran atau Tahfizh Champ 4 . Dengan jumlah pelajar yang sedang menghafal Alqurannya mencapai ribuan santri. Para pelajar ini berasal dari berbagai daerah di Indonesia, semuanya bertemu dan berusaha menghafalkan ayat demi ayat yang terdapat dalam Alquran.

Pesantren Tahfizh Daarul Qur'an pusatnya berada di Cipondoh Tangerang, selain itu pula, Pesantren Tahfizh Daarul Qur'an juga terdapat dibeberapa tempat. Pertama di Cikarang, yakni pesantren khusus putri dengan menyelenggarakan pendidikan formal juga di dalamnya. Kedua, di Ungaran Semarang, ketiga, di Lampung. Untuk saat ini sedang berlangsung pembangunan Pesantren Tahfizh Daarul Qur'an di Jambi, Cilegon, dan Banyuwangi. ${ }^{5}$ Tidak hanya menyelenggarakan pesantren tahfizh Alquran, Daarul Qur'an sendiri pun mengembangkan Rumah Tahfizh Alquran yang telah tersebar 2000 di seluruh Indonesia. ${ }^{6}$ Pembinaan Tahfizh Alquran di Pesantren Tahfizh Daarul Qur'an menggabungkan model pendidikan pesantren dan pendidikan sekolah. Anak didik tidak sebatas menghafal Alquran, sebagian waktunya masuk kelas formal seperti pelajar yang belajar di sekolah-sekolah pada umumnya.

\section{Mengenal Tahfizh Alquran}

Menghafal dalam bahasa arab dikenal dengan sebutan al - hifdz

\footnotetext{
${ }^{4}$ Sumber http://daqu.sch.id/, diakses pada 11 Oktober 2016

${ }^{5}$ Sumber http://www.pppa.or.id/ , diakses pada 11 Oktober 2016

${ }^{6}$ Sumber http://rumahTahfizh.or.id/content.php?ct=tentang, diakses pada 11 Oktober 2016
} 


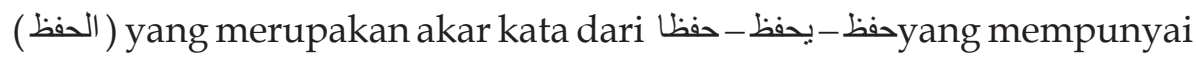
arti 'menjadi hafal dan menjaga hafalannya atau memelihara, menjaga, menghafal dengan baik' ${ }^{7}$

Orang yang hafal Alquran dikenal dengan sebutan haafidz (حافظ ), yaitu orang yang menghafal dengan cermat, termasuk sederetan kaum yang menghafal. ${ }^{8}$

Ibnu Mandzur sebagaimana dikutip oleh Abdulrab Nawabuddin mengartikan haafidz adalah orang yang berjaga - jaga, yaitu orang yang selalu menekuni pekerjaannya. ${ }^{9} \mathrm{Hal}$ ini didasarkan pada Firman Allah SWT dalam surat al-Baqarah ayat 238 sebagai berikut:

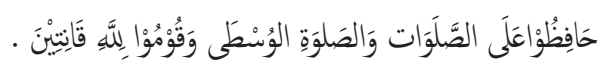

“ (QS. Al-Baqarah 2: 238) ${ }^{10}$

Kata al-hifdz banyak ditemukan dalam Alquran, namun kata tersebut memiliki arti yang beragam sesuai dengan konteks ayat masing - masing, misalnya dalam surat Yusuf ayat 65 sebgai berikut :

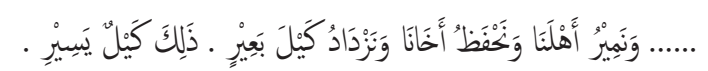

dan kami akan dapat memelihara saudara kami.... (QS. Yusuf 12: 65$)^{11}$

Lafadz hafidz dalam ayat tersebut brarti memelihara dan menjaga. Al-hifdz juga memiliki makna lain, sebagaimana dalam surat al$\mathrm{Mu}$ 'minun ayat 5 sebagai berikut:

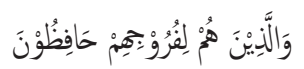

Dan orang - orang yang menjaga kemaluannya.(QS. AlMu'minun40: 5) ${ }^{12}$

Lafadz al-hifdz yang dimaksudkan dalam ayat tersebut adalah menahan diri dari hal - hal yang diharamkan Allah SWT. Makna lain dari al-hifdz juga dapat dilihat dalam surat al-Anbiya ayat 32 sebagai berikut:

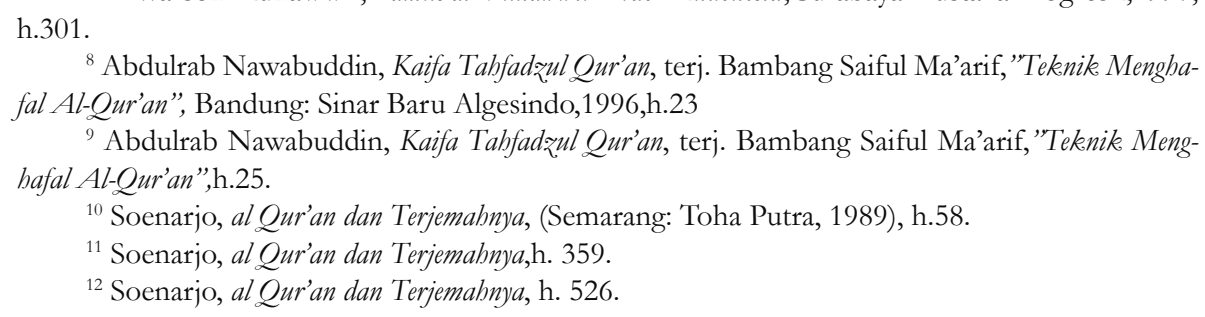
h.301.

${ }^{8}$ Abdulrab Nawabuddin, Kaifa Tahfadzul Qur'an, terj. Bambang Saiful Ma'arif,'Teknike Menghafal Al-Qur'an”, Bandung: Sinar Baru Algesindo,1996,h.23

'Abdulrab Nawabuddin, Kaifa Tabfadzul Qur'an, terj. Bambang Saiful Ma'arif,'Teknik. Menghafal Al-Qur'an",h.25.

${ }^{10}$ Soenarjo, al Qur'an dan Terjemahnya, (Semarang: Toha Putra, 1989), h.58.

${ }^{11}$ Soenarjo, al Qur'an dan Terjemahnya,h. 359.

${ }^{12}$ Soenarjo, al Qur'an dan Terjemahnya, h. 526.

${ }^{7}$ A. Warson Munawwir, Kamus al Munawwir Arab - Indonesia, Surabaya: Pustaka Progresif,1997, 


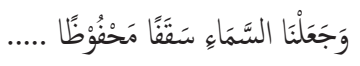

Dan kami menjadikan langit itu sebagai atap yang terpelihara. (QS. Al-Anbiya 21: 32) (13 $^{13}$

Dari pengertian tersebut, dapat diambil pengertian bahwa makna menghafal (al-hifdz) memiliki banyak pengertian. Banyaknya makna "menghafal" dalam Alquran pada dasarnya terletak dari konteks makna tersebut digunakan.

Kedua, pengertian Alquran secara etimologis Alquran berarti "bacaan" atau yang dibaca. ${ }^{14}$ Kata tersebut berasal dari qara'a (قرأ ) yang berarti membaca. ${ }^{15}$

Definisi yang samasebagaimana diungkapkan oleh Abu Yahya Zakaria al-Anshari dalam kitab Ghayah al Wushul: Syarah Lub al Ushul:

"Alquran adalah lafadz yang diturunkan kepada Nabi Muhammad SAW, yang bisa menjadi mu'jizat dengan satu surat darinya serta menjadi ibadah bagi orang yang membacanya".

Dari pengertian "menghafal" dan "Alquran" tersebut dapat diambil pengertian, bahwa menghafal Alquran adalah suatu proses untuk menjaga dan memelihara Alquran di luar kepala (mengingat) dengan baik dan benar dengan syarat dan tata cara yang telah ditentukan.

Abdulrab Nawabuddin sendiri berpendapat bahwa makna etimologis menghafal Alquran berbeda dengan menghafal selain Alquran. Perbedaan ini dikarenakan dua alasan. Pertama, menghafal Alquran adalah hafal secara sempurna seluruh Alquran, sehingga orang yang hafal Alquran separuh atau sepertiganya belum dikatakan sebagai haafidz (orang yang hafal Alquran). Kedua, menghafal Alquran harus kontinyu dan senantiasa menjaga yang dihafal itu supaya tidak lupa. Orang yang hafal Alquran, kemudian lupa sebagian saja atau seluruhnya karena kealpaan atau karena sebab lain, misalnya sakit atau menjadi tua, maka tidak berhak menyandang sebagai haafidz. ${ }^{16}$

Pendapat Abdul Rab bila diteliti merupakan rambu - rambu

\footnotetext{
${ }^{13}$ Soenarjo, al Qur'an dan Terjemahnya, h. 499.

${ }^{14}$ Muslim Nurdin dkk, Moral dan Kognisi Islam, Jawa Barat: Alfabeta, 2001, hlm. 48.

${ }^{15}$ Lihat, QS. Al-Qiyamah : 18

${ }^{16}$ M. Ziyad Abbas, Metode Praktis Menghafal Alquran, Jakarta: Firdaus, 1993,h.29-30.
} 
sekaligus kehati-hatiannya dalam memberi gelar haafidz, karena seseorang dikatakan haafidz harus memenuhi beberapa persyaratan dan dibatasi pengertiannya sebagai berikut: a. Seorang haafidz harus hafal Alquran secara keseluruhan (30 Juz) sehingga seseorang belum dikatakan sebagai haafidz bila hanya hafal Alquran sebagian, sepertiganya, seperempatnya dan sebagainya. b. Seseorang dikatakan haafidz jika dapat menjaga hafalannya dari kelupaan. Seseorang yang sudah menghafal Alquran secara keseluruhan, namun karena ada sebab (misalnya sakit atau proses penuaan) dan lupa sebagian Alquran maupun keseluruhannya, maka dia tidak berhak mendapat sebutan haafidz lagi.

Ahsin W. Al-Haafidz mendefinisikan menghafal Alquran adalah langkah awal untuk memahami kandungan ilmu - ilmu Alquran yang dilakukan setelah proses membaca dengan baik dan benar. ${ }^{17}$

Dari definisi dan pengertian yang dikemukakan oleh para ahli tersebut dapat diambil pengertian bahwa menghafal Alquran adalah proses untuk memelihara, menjaga dan melestarikan kemurnian Alquran di luar kepala agar tidak terjadi perubahan dan pemalsuan serta dapat menjaga dari kelupaan baik secara keseluruhan maupun sebagiannya.

\section{Faktor-faktor yang mempengaruhi hafalan Alquran}

Faktor-faktor yang mendukung seseorang dalam menghafal Alquran adalah sebagai berikut : (1)Persiapan yang matang (2) Motivasi dan stimulus ${ }^{18}$ (3)Faktor Usia (4) Manajemen waktu

Sedangkan menurut Raghib As Sirjani dalam bukunya Cara Cerdas Hafal Alquran mencantumkan kaidah pokok, kaidah pendukung dan kaidah-kaidah emas dalam menghafal Alquran.Pertama, Kaidah mendukung; Ikhlas, Tekad yang kuat dan bulat, pahamilah besarnya nilai amalan anda, amalkan apa yang anda hafalkan, membentengi diri dari jerat-jerat dosa, berdoalah, pahamilah makna ayat dengan benar, menguasai ilmu tajwid, sering mengulang-ulang bacaan, melakukan shalat secara khusyuk dengan ayat-ayat yang telah dihafal. Kedua, Kaidah pendukung; membuat perencanaan yang jelas, bergabung

${ }^{17}$ Ahsin W. Al-Hafidz, Bimbingan Praktis Menghafal Alquran, Jakarta: Bumi Aksara, 2005, h. 19.

${ }^{18}$ Abdulrab Nawabuddin, Kaifa Tahfadzul Qur'an, terj. Bambang Saiful Ma'arif,'Teknik. Menghafal Al-Qur'an, h. 48-49. 
dalam sebuah kelompok, bawalah alquran kecil dalam saku, dengarkan bacaan Imam saat shalat, mulai dari juz yang alquran mudah dihafal, gunakan satu jenis mushaf alquran, membagi surat yang panjang, memperhatikan ayat-ayat mutsyabihat, perlombaan menghafal alquran. Ketiga, Kaidah-kaidah emas; hendaknya membatasi porsi hafalan untuk setiap harinya, jangan menghafal melebihi batasan harian sampai hafal sempurna, jangan beralih ke surat lain sebelum benar-benar hafal, senantiasa meperdengarkan hafalan ke guru, manfaatkan usia emas dalam menghafal. ${ }^{19}$

Ahsin W. Al-Haafidz dalam bukunya Bimbingan Praktis Menghafal Alquran telah meninventarisir waktu - waktu yang dianggap ideal untuk menghafal Alquran sebagai berikut: (a)Waktu sebelum fajar (b)Setelah fajar, sehingga terbit matahari (c)Setelah bangun dari tidur siang (d)Setelah shalat (e)Waktu di antara Maghrib dan Isya (f) Intellegensi dan potensi ingatan (g)Tempat menghafal (h)Panjang dan pendek surat atau ayat ${ }^{20}$

Selain faktor-faktor pendukung tersebut, faktor-faktor lain yang harus diperhatikan adalah faktor penghambat (kendala) menghafal Alquran. Faktor-faktor penghambat dalam menghafal Alquran diantaranya: (a)Banyaknya dosa dan maksiat (b)Tidak adanya upaya untuk menjaga hafalan (c)Perhatian yang berlebihan terhadap urusan dunia (d)Berambisi menghafal ayat - ayat yang banyak dalam waktu yang singkat. ${ }^{21}$

\section{Pembinaan Program Tahfidz Alquran di Pesantren Tahfidz Daarul Qur'an}

Pesantren Tahfizh Daarul Qur'an dengan program pengkhususan dan penguatan pada Tahfizh Alquran. Tahfizh Qur'an ini menjadi prioritas dalam setiap kebijakan dan program-program pendidikan yang dikembangkannya. Bagi siswa akhir SMP-SMA yang mau lulus dari sekolah, tidak cukup lulus nilai Ujian Nasional, untuk bisa lulus dari pesantren. Siswa harus tercapai target hafalan Alqurannya, tiap tahun 3 juz, dengan minimal hafal 9 Juz bagi kelas 3 SMP, sedangkan kelas 3 SMA beberapa siswa ada yang sudah mengkhatamkan 30 juz

\footnotetext{
${ }^{19}$ Raghib As Sirjani, Cara Cerdas Hafal Al Qur'an, Solo: Aqwam, 2013. h. 55-123

${ }^{20}$ Ahsin W. Hafidz, Bimbingan Praktis Menghafal Alquran, h. 61.

${ }^{21}$ Ummu Abdillah \& Ummu Maryam, Bandung: Pustaka Kautsar, 2012, h. 3.
} 
hafalan alquran, selain itu juga siswa akhir harus mampu lulus ujian pelajaran Dirasah Islamiyah.

Dalam penyusunan kurikulum di pesantren Tahfizh Daarul Qur'an, Pesantren Tahfizh Daarul Qur'an memadukan tiga model kurikulum. Setiap siswa belajar dan mendapat pengalaman pendidikan materi-materi pelajaran sebagaimana yang perlu dipenuhi dalam Kurikulum Akademik Nasional (Diknas), Kurikulum Pendidikan Agama Islam (Dirasah Islamiyah) dan Kurikulum Tahfizh Alquran. Dengan pengaturan alokasi waktu yang sangat padat dan teratur.

Kurikulum Tahfizh Alquran di Pesantren Tahfizh Daarul Qur'an disusun secara khas dan tersendiri. Alokasi waktu pembelajaran dilakukan selepas shalat shubuh sampai 06.45 WIB dan setelah shalat Ashar sampai menjelang Maghrib pukul 18.00. Secara penyusunan waktu, pembelajaran Tahfizh Alquran tidak mengganggu waktu kegiatan belajar mengajar siswa di sekolah.

Dapat digambarkan penyusunan model kurikulum pendidikan di Pesantren Tahfizh Daarul Qur'an sebagaimana di bawah ini;

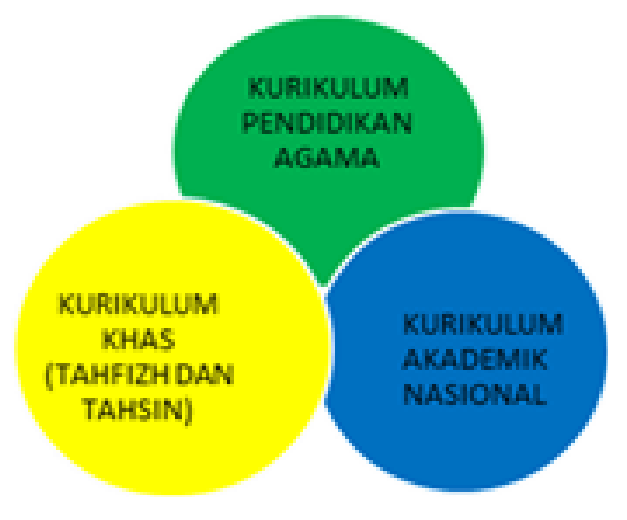

Gambar. Kurikulum Pendidikan Agama, Kurikulum Akademik Nasional dan Kurikulum Khas (Tahfizh dan Tahsin). ${ }^{22}$

Pembelajaran Tahfizh Alquran menggunakan metode dan panduan Tahfizh Qoidah Nuraniyah. Qoidah Nuraniyah merupakan sebuah sistem pembelajaran yang menggabungkan cara membaca, tahsin dan Tahfizh Alquran secara berkesinambungan, harian, terukur dan tercatat dengan rapih.

Metode ini dipopulerkan ke Indonesia oleh Syeikh Muhammad

${ }^{22}$ Tim Litbang Daarul Qur'an, Panduan Kurikulum Pesantren Tahfiž Daarul Qur'an 2015 
ar-Ra'i, yang datang dari negeri Arab. Beliau hadir di Indonesia untuk yang pertama kalinya, yang bertepatan dengan acara daurohasatidz di pesantren Daarul Qur'an Ketapang. ${ }^{23}$ Dan akhirnya metode ini direkomendasikan untuk diimplementasikan sebagai metode Tahfizh unggulan di Pesantren Daarul Qur'an, baik di pusat maupun di semua cabang Pesantren Daarul Qur'an.

\section{Tahap Penyusunan Pembinaan Tahfizh Alquran}

Tahfizh Alquran menjadi cita-cita awal dan fokus pendirian pesantren Tahfizh Daarul Qur'an, untuk menyukseskannya membutuhkan suatu rumusan yang menyeluruh, utuh dan detail konsep pengembangannya. Rumusan pembinaan tahfizh Alquran menjadi sesuatu yang urgen. Dengan pengalaman dalam pembinaan tahfizh Alquran yang telah dilaksanakan, Pesantren Tahfizh Daarul Qur'an telah merumuskan konsep dan praktik pembinaan tahfizh Alquran. Sebagaimana hasil wawancara dengan Ustadz Muhaimin, selaku kepala biro tahfizh Alquran Pesantren Tahfizh Daarul Qur'an. Kepala biro Tahfizh bertugas menyukseskan penyelenggaraan pembelajaran Tahfizh Alquran di Pesantren tahfizh Daarul Qur'an baik pusat maupun cabang. Dalam merumuskan dan merancang suatu pembinaan tahfizh Alquran dengan mempertimbangkan beberapa faktor; Pertama, melihat kondisi objektif santri. Apakah santri yang masuk sudah atau belum pandai membaca Alquran?. Bagi yang sudah bagus bacaan Alqurannya, masuk sudah dipersilahkan untuk menghafal. Bagi yang belum, diwajibkan Tahsin dulu. Bahkan kalau belum bisa sama sekali, diawali dari belajar membaca Alquran. Kedua, dikelompokkan sesuai kemampuan. Misalkan Mubtadi, Tahsin dan Tahfizh sendiri. Untuk menunjangnya, maka dibuat Daily Activity yang menjadi pakem bagi santri dan guru menjadi jam wajib untuk belajar dan mengajar Alquran. ${ }^{24}$

Berdasarkan hasil wawancara di atas, Informasi awal yang objektif tentang keadaan dan kemampuan santri benar-benar menjadi dasar dalam perumusan suatu pembinaan Tahfizh yang akan diselengarakan. Informasi yang berkaitan dengan anak didik yang

${ }^{23}$ Dauroh Tahfizh bersama Syeikh Muhammad Faruq Muhammad Ar-Raa'i, di Pesantren Tahfizh Daarul Qur'an Ketapang.

${ }^{24}$ Wawancara dengan Muhaimin, Selaku Kepala Biro Tahfizh Al Qur'an Pesantren Tahfizh Daarul Qur'an. Dilaksanakan pada 19 November 2016 di Kantor Biro Tahfizh 
akan menghafal Alquran tidak semata menempatkannya sebagai objek, tetapi sebagai subjek dari suatu program pembinaan Tahfizh di pesantren Tahfizh Daarul Qur'an. Dengan informasi tentang anak didik ini pembagian halaqoh dimulai dari kelompok Mubtadi bagi santri yang baru pertama kali belajar Alquran artinya bagi santri yang belum bisa membaca Alquran. Pembagian halaqoh selanjutnya adalah halaqoh tahsin, diperuntukkan bagi santri-santri yang sudah bisa membaca Alquran, namun masih belum lancar dan penguasaan bacaan Alquran sesuai ilmu tajwid masih lemah. Selanjutnya halaqoh Tahfizh, bagi kelompok ini setiap santrinya sudah diperkenankan untuk menghafal Alqurannya sendiri kepada ustadz halaqohnya.

Peranan ustadz tahfizh memiliki posisi penting dan tidak tergantikan dalam pembinaan Tahfizh. Syarat mutlak yang diperlukan bagi guru tahfizh di pesantren tahfizh Daarul Qur'an dengan memiliki hafalan Alquran lengkap dan mutqin. Ketidak mampuan guru dalam mengajar tahfizh menjadikan pembinaan tahfizh Alquran dijalankan oleh orang-orang yang tidak memiliki keilmuannya. Akibatnya tahfizh Alquran yang dimiliki anak-anak tidak layak bahkan menjadi suatu kesalahan, dan ini bisa mendatangkan suatu dosa. Karena objek yang dihafal sendiri, yaitu Alquranul Karim. Kesalahan dalam mengajarkan Alquran terlebih kesalahan tersebut telah dihafalkan oleh santri dan tidak ada yang membenarkan berarti santri tersebut memiliki hafalan yang salah yang dia sendiri tidak mengetahui letak kesalahannya, Ini kesalahan terbesar yang dilakukan oleh pengajar tahfizh Alqurannya. Oleh karena itu dalam penyusunan pembinaan tahfizd Alquran keberadaan guru-guru yang berkualitas dalam bidang tahfizh menjadi pertimbangan tersendiri.

Dari informasi ini juga diketahui, bahwa pesantren tahfizh Daarul Qur'an belum menyeleksi secara ketat calon santri-santrinya yang akan masuk ke pesantren. Calon santri yang akan menghafal Alquran. Tentunya dalam menghafal Alquran memiliki tahapan tidak serta merta langsung bisa menghafal. Bagi santri yang sudah bisa membaca Alquran dengan tajwidnya tentu menghafal Alquran sudah bisa langsung dilakukan. Namun bagi santri yang belum bisa sama sekali membaca Alquran tentunya ini menjadi kendala dan tantangan tersendiri bagi pesantren dalam merumuskan 
pembinaannya. Perbedaan kemampuan anak didik yang masuk ke pesantren menjadikan perbedaan pola dan bimbingan yang dilakukan. Perbedaan ini terlihat dari penyelenggaraan halaqoh Alquran. Dimana ada halaqoh tahfizh dan ada halaqoh tahsin. Dengan adanya dua model halaqoh ini menunjukkan pembinaan tahfizh Alquran telah dilakukan dengan melihat kemampuan santrinya.

Selain faktor santri sebagai anak didik yang akan menghafal Alquran, faktor pertimbangan dalam merumuskan konsep dan praktik dalam pembinaan tahfizh Alquran di pesantren tahfizh Daarul Qur'an dengan melihat kemampuan tenaga pendidik Alquran sendiri, dalam hal ini guru-guru tahfizh Alquran sendiri. Guru tahfizh memiliki peran sangat besar dan strategis dalam membina dan menyukseskan target hafalan Alquran para santrinya. Oleh karena itu, pesantren tahfizh telah mempertimbangkan dan membuat suatu kebijakan dalam menyeleksi guru-guru tahfizh Alqurannya. Sebagaimana pernyataan dari Muhaimin, kepala biro tahfizh Daarul Qur'an;

Pertama, dibuat standarisasi bagi guru Tahfizh. Guru yang masuk Daarul Qur'an, bukan sekadar bacaan dan menghafal Alquran saja. Dengan standarisasi pertama minimal telah selesai 30 juz Alquran. Kedua, guru memiliki minimal 10 juz yang mutqin. Untuk menunjangnya disiapkan program setoran bagi guru-guru tahfizh kepada Syaikh-syaikh yang ada di Daarul Qur'an. Yaitu program Markaz I'dad Muallimin yang menjadi cikal bakal mempunyai guruguru Tahfizh di bidang Alquran. ${ }^{25}$

Berdasarkan hasil wawancara di atas, pembinaan tahfiz Alquran juga dilakukan pada guru-guru tahfizh Alquran di Pesantren Tahfizh Daarul Qur'an sendiri. Guru tahfizh yang berkualitas memudahkan pencapaian target hafalan Alquran bagi santri-santrinya. Pembinaan bagi guru tahfizh dimulai dengan membuat ketentuan bagi calon guru-guru Tahfizh yang layak diterima dan mengajar tahfizh Alquran. Ketentuan ini dijalankan dengan seleksi yang ketat, terlebih pada kemampuan calon guru tahfizh sendiri yang harus telah memiliki hafalan Alquran 30 juz, dengan memiliki hafalan Alquran 10 juga yang benar-benar hafal. Dengan adanya ketentuan ini, guru

${ }^{25}$ Wawancara dengan Muhaimin, Selaku Kepala Biro Tahfizh Al Qur'an Pesantren Tahfizh Daarul Qur'an. Dilaksanakan pada 19 November 2016 di Kantor Biro Tahfizh al Qur'an Ketapang, Kota Tangerang. 
tahfizh Alquran di Pesantren Tahfizh Daarul Qur'an sudah memiliki keilmuan dasar yang dibutuhkan. Pembinaan bagi guru tahfizh juga dilakukan bagi guru-guru tahfizh Alquran lainnya. Pembinaan dengan penyelenggaraan tahfizh intensif, dimana setiap guru tahfizh diwajibkan untuk memoraja'ah hafalannya kepada syaikh Ahmad Al Kannas. Dengan adanya kegiatan setoran guru tahfizh kepada syaikh menunjukkan pembinaan tahfizh Alquran telah berlangsung kepada guru-guru tahfizhnya. Tentunya pembinaan tahfizh Alquran ini memiliki peran sangat strategis dalam peningkatan mutu dan kualitas pelaksanaan tahfizh yang berdampak langsung pada pencapaian kualitas hafalan anak santri. Para santri tidak semata dituntut untuk memiliki hafalan 30 juz, disamping itu, hafalan Alqurannya benarbenar berkualitas.

Dari informasi di atas, dapat dirumuskan juga pembinaan tahfizh Alquran bagi guru-guru tahfizh Alquran di Pesantren Tahfizh Daarul Qur'an;

Pertama, penyeleksiaan guru-guru Tahfizhh Alquran semakin sistematis dan ketat lagi. Dipastikan guru-guru yang mengajar Tahfizh memiliki kapabilitas dalam tahfizh dan mengajarkan Tahfizh Alquran kepada para santrinya.

Kedua, Pelatihan pengajar tahfizh Alquran. Dalam rangka mengupgrade terus menerus kemampuan guru-guru Tahfizhnya. Upaya ini adalah tindakan tepat demi menjamin mutu dan kualitas yang berinteraksi langsung dengan para santri. Sehingga dipastikan setiap santri di pesantren Tahfizh Daarul Qur'an diajar oleh guru-guru yang berkualitas pula dalam bidang Tahfizh Alqurannya.

Ketiga, Pembagian halaqoh Tahfizh dengan diberikan perangkat administrasi bagi guru tahfizh sebagai form penilaian tahfizh harian santri. Per halaqoh tahfizh diatur satu guru tahfizh dengan 15 santri sebagai anak didik binaannya dalam tahfizh.

Keempat, Penyusunan dan sosialisasi ketentuan-ketentuan dalam menyelenggarakan pelaksanaan pembelajaran tahfizh Alquran. Dengan adanya ketentuan yang ada menjadi role dan panduan setiap guru tahfizh dalam pembelajaran Tahfizh Alquran yang dilaksanakannya. 


\section{Tahap pelaksanaan pembinaan tahfizh Alquran dan Pembelajaran Tahfizh di Pesantren Tahfizh Daarul Qur'an}

Secara umum kegiatan Tahfizh di Pesantren Tahfizh Daarul Qur'an terdiri dari beberapa kegiatan, antara lain:

\section{1) Talqin}

Talqin secara bahasa berarti memahamkan, sedangkan menurut istilah adalah mengajarkan ucapan, kata-kata atau ayat-ayat dalam Alquran yang kemudian ditirukan oleh santri atau pendengar. Apabila da kekurangan atau kesalhan dalam pengucapan seperti panjang pendek, makhraj al-huruf dan sifat huruf, maka ustadz langsung membetulkannya. Talqin ini wajib bagi para anak-anak dan pemula yang ingin menghafal Alquran dan belum memilikai bacaan yang baik dan benar, juga bagi orang dewasa yang masih merasa kesulitan membaca Alquran. Kegiatan talqin di Pesantren Tahfizh Daarul Qur'an wajib bagi setiap santri yang akan menyetorkan hafalan. Ada dua macam talqin, yaitu talqin fardi atau sendiri-sendiri antar ustadz dengan satu orang santri dan talqin jama'i atau bersama-sama antara satu ustadz dengan dua santri atau lebih.

a) Talqin Fardi

Ada tiga cara dalam melaksanakan talqin fardi, yaitu: (1)Ustadz membacakan surah, ayat atau gabungan ayat dalam Alquran dengan suara yang lantang dan jelas di depan santri kemudian santri tersebut untuk mengulangi apa yang sudah didengar. (2) Santri membacakan ayat yang sudah dihafalkan. Apabila terdapat kesalahan dalam membaca seperti sifat huruf, makhariju al-huruf maka ustadz atau guru akan membetulkannya. (3) Santri mendengarkan kaset atau rekaman seorang qari yang direkomendasikan oleh ustadz.

b) Talqin Jama'i

Talqin jama'i dilaksanakan seperti talqin fardi tetapi secara bersamasama dengan seorang ustadz atau juga bisa menggunakan video. Talqin fardi dilaksanakan oleh santri bersama musyrifnya seminggu sekali, dilaksanakan pada hari sabtu jam tahfizh setelah shalat Ashar menjelang Maghrib. ${ }^{26}$

\section{2) Tasmi'}

Tasmi' secara bahasa berarti memperdengarkan sedangkan secara

26 Wawancara dengan ustadz Sodriqun Nawa, salah satu musyrif halaqah, pada hari sabtu 18 November 2016. 
istilah adalah menyetorkan hafalan Alquran kepada seorang ustadz dalam sebuah halaqah. Kegiatan tasmi' di Pesantren Tahfizh Daarul Qur'an dilaksankan setiap hari.

Kegiatan tasmi' dilaksanakan setiap hari kecuali hari libur yaitu hari jum'at. Jumlah hafalan yang harus disetorkan atau disima'kan minimal 3 halaman. Kegiatan tasmi' dilakukan tiga kali sehari, apabila ada santri belum bisa menyetorkan hafalan di jam pagi, maka diharuskan menyetorkannya di waktu halaqah sore. ${ }^{27}$ Setiap musyrif halaqah di wajibkan menuliskan perkembangan hafalan santri di dalam buku kasyful mutaba'ah atau buku buku catatan hafalan Alquran. Sehingga penanggung jawab bagian keTahfizhan bisa melihat hasil perkembangan hafalan santri.

3) Muroja'ah

Muroja'ah secara bahasa adalah pembiasaan. Sedangkan menurut istilah adalah kegiatan mengulang hafalan Alquran. Muroja'ah harus dilakukan dan wajib bagi para penghafal Alquran. Mengulangi hafalan membutuhkan keistiqomahan. Dan ketekunan untuk mencegah lupa atau hilangnya hafalan. Muroja'ah Alquran yang ditetapkan di Pesantren Tahfizh Daarul Qur'an ada tiga metode, yaitu:

a) Muroja'ah dengan Musyrif

Kegiatan mengulangi hafalan bersama musyrifhalaqah dilaksanakan ketika dalam halaqahpada jam kedua atau ba'da asar. Apabila santri belum bisa menyetorkan hafalan di pagi hari atau karena kehabisan waktu, maka di perbolehkan menyetorkan Muroja'ah hafalan di sore hari ba'da asar. Target yang di wajibkan untuk di Muroja'ah dalam sehari adalah sepuluh persen dari jumlah seluruh hafalan yang dimiliki santri.

\section{b) Muroja'ah dengan teman}

Muroja'ah dilaksanakan pada saat jam Muroja'ah, para santri di haruskan menyimakan hafalan ketemannya sebanyak lima lembar perhari ke temannya yang telah di tentukan oleh musyrif halaqah sebagai satu pasangan setoran hafalan. Kegiatan muroja'ah dengan teman ini sifatnya fleksibel, tergantung keputusan masing-masing musyrif halaqah.

c) Muroja'ah fardiah atau mengulang hafalan sendiri

27 Wawancara dengan ustadz Sodriqun Nawa, salah satu musyrif halaqoh, pada hari sabtu 18 November 2016. 
Muroja'ah fardiah dilaksanakan sesuai denga inisiatif santri dengan menyesuaikan target yang telah disepakati oleh musyrif halaqah. Berdasarkan pengamatan peneliti di lapangan, muroja'ah fardiah sangat membutuhkan kesadaran diri dari setiap santri. Ada santri yang mengulang hafalan sebanyak 5 juz atau tiga juz sehari. Santri dalam mengulang hafalan ada yang membaca dengan melihat ke mushaf ada juga yang tanpa melihat mushaf, tetapi apabila ada kesalahan baru membuka mushaf Alquran. Muroja'ah fardiah juga bisa dilakukan setiap ada kesempatan untuk mengulang hafalan.

Kegiatan Muroja'ah dengan tiga cara di atas dipantau langsung oleh musyrif halaqah dengan menanyakan jumlah muroja'ah yang diperoleh selama satu hari, dan mencatatnya di lembar catata hafalan Alquran santri.

4) Al-Qaidah An-Nuroniyyah

Qoidah An-Nuroniyah adalah buku panduan mengenai metode membaca Alquran dengan cepat yang digunakan Pesantren Tahfizh DaarulQur'an. Buku ini adalahkaryaSyeikh Nur Muhammad Haqqoni, yang kemudian disebarluaskan oleh cucunya Ir. Muhammad Farouq Ar-Ro'i. Ir. Farouq adalah pimpinan Markaz Pembelajaran Alquran Al-Furqon yang berpusat di Jeddah Saudi Arabia. Metode Qoidah an-Nuroniyah sendiri telah dijadikan metode pembelajaran Alquran yang resmi digunakan di Masjid Al-Haram dan Masjid An-Nabawi di Madinah al-Munawwarah. Selain itu, metode ini telah digunakan di 35 negara seluruh dunia. ${ }^{28}$

Buku Qoidah an-Nuroniyah terdiri dari 17 chapter, dimuli dari pelajaran mendasar mengenai pengenalan huruf hijaiyyah dengan penekanan makhorijul huruf, selanjutnya huruf hijaiyyah yang bergandeng, dilanjutkan dengan pengenalan harokat, dan sampai pada akhirnya belajar membaca ragaian bacaan Alquran yang cukup panjang.

Dilihat dari konten buku Qoidah an-Nuroniyah, sebenarnya tidak terlalu jauh sebagaimana metode Baghdadiyah yang ada di Idonesia. Kelebihan yang dimiliki Nuroniyyah adala karena ia memiliki perangkat pembelajaran lainnya sebagai pelegkap dengan memanfaatkan teknologi sebagai basis pengembangannya. Sehingga Nuroniyah disamping dicetak dalam bentuk buku, ia juga hadir dan

${ }^{28}$ Dokumentasi Tim Biro Tahfiz al Qur'an, Panduan Pembelajaran Tahfizh di Pesantren Tahfizh Daarul Qur'an 2015 
menjadi sumber pembelajaran Tahfizh dalam bentuk lainnya seperti poster, CD, DVD, terdapat di aplikasi PlayStore, dalam bentuk Card, dan dalam bentuk lainnya yang menjadikan Nuroniyyah terasa lebih up to date. ${ }^{29}$ Dengan begitu pembelajar Nuroniyyah juga selain mendapat bimbingan dari guru, dapat memanfaatkan CD atau DVD sebagai sumber belajar yang dapat didikuti kapan saja dan di mana saja. Selain itu, Nuroniyyah juga memiliki karakter khusus berupa ketentan intonasi dalam setiap chapternya. Dengan begitu proses pembelajaran Nuroniyyah terasa lebih semarak, menyenangkan, dan memiliki kesan khusus bagi pembelajar.

Jalinan kerjasama Markaz Al-Furqon dan Daarul Qur'an diawali dengan pertemuan Pimpinan Daarul Qur'an di Jeddah, selanjutnya lembaga Daarul Qur'an mengundang Ir. Faruq untuk mengadakan pelatihan kepada guru-guru Tahfizh Daarul Qur'an. Tahap selanjutnya ditindak lanjuti degan pertemuan dan dicapai kesepakatan untuk bekerjasama antara Daarul Qur'an dan Markaz Al-Furqon. Daarul Qur'an selanjutnya menjadi perwakilan Al-Furqon di wilayah Asia Tenggara.

Didalam buku Qoidah an-Nuroniyah berisi materi pelajaran tajwid dan tahsin secara teori dan prakteknya. Berdasarkan hasil wawancara dengan ustadz Muhaimin, selaku kepada Biro Tahfizh Daarul Qur'an menjelaskan alasan penggunaan Qoidah an-Nuroniyah dalam pembinaan tahfizh di Pesantren Tahfizh Daarul Qur'an sebagaimana berikut;

Pesantren Daarul Qur'an memakai Qoidah Nurroniyah dalam pembelajaran tahfizh Alquran, Qoidah Nurroniyah dipilih karena memiliki beberapa keunggulan. Pertama, kitabnya tipis, simple, dan penuh syarat ilmu. Contoh jika dibandingkan dengan metode belajar Alquran lainnya. Rata-rata lebih dari 300 halaman. Qoidah Nurroniyah sekitar 26 halaman, mewakili kaidah seluruh membaca Alquran. Kelebihan kedua, lebih menitik beratkan pada makhraj. Anak-anak dipastikan makhrajnya bagus, dan melafazkan sifat huruf-huruf Alqurannya fasih. Kelebihan ketiga yang specialnya, yaitu mendapatkan dua ilmu sekaligus ilmu bisa membaca Alquran dan menulis Alquran. Karena cara belajarnya mengharuskan santri mengeja satu bacaan dengan menggerakkan jari mengikuti tulisannya.

29 Dokumentasi buku Qoidah an-Nuroniyah, Jedah: Markaz Al-Furqon 
Agar santri makhrajnya benar dan menguasai menulis Alquran dan tidak memakan waktu yang lama, yakni cukup 3 bulan saja. ${ }^{30}$

Dalam praktek pembelajaran tahfizh Alquran di halaqoh, kaidah an-Nuroniyah dipadukan dengan Dalil Sanawi sebagai satu paket di dalamnya. Dalam Dalil Sanawi dibuat empat poin penilaian yang perlu dicapai oleh santri setiap pertemuan tahfiznya. Poin pertama dari hafalan baru, point kedua dari poin ketiga dari muraja'ah hafalan lama, poin keempat dari penilaian akhlak dan disiplin. Akhlak nilainya setengah dan disiplin nilainya setengah. ${ }^{31}$ Maka jika santri mampu mendapatkan satu poin dari masing-masing ketentuan, santri tersebut mendapat nilai 4 penuh. Kalau datang tetapi tidak setoran, ia mendapat hanya nilai akhlak dan disiplin. Adanya sistem poin dapat terlihat akumulasi nilai dari pembelajaran tahfizh yang sudah berlangsung dalam satu pekan, satu bulan, satu semester bahkan satu tahun.

\section{Prosedur Pelaksanaan Kegiatan Tahfizh di Pesantren Tahfizh Daarul Qur'an}

Petunjuk pelaksanaan kegiatan Tahfizh diatur sebagaimana ketentuan berikut: (1)Guru Tahfizh mengenakan pakaian seragam saat mengajar Tahfizh (seragam sesuai dengan ketentuan). (2) Santri wajib mengenakan seragam setiap kegiatan Tahfizh sesuai dengan ketentuan, kecuali Tahfizh ba'da subuh. (3)Santri wajib datang di halaqoh 5 menit sebelum masuk waktu Tahfizh. (4)Dalam memulai kegiatan Tahfizh, Guru Tahfizh dan santri membaca doa secara bersama-sama, setelah sebelumnya Guru Tahfizh memberi salam. (5)Bagi santri yang terlambat diberikan pembinaanberupa berdiri 10 menit. (6) Santri wajib membawa peralatan Tahfizh (Kitab Qoidah Nuroniyah, mushaf yang ditentukan, dan alat tulis, dan dimasukkan ke dalam tas Tahfizh). (7)Santri wajib duduk secara tertib dan rapi sesuai dengan yang ditentukan guru Tahfizh. (8)Santri dilarang keluar halaqoh tanpa seijin guru Tahfizh. (9)Santri tidak boleh keluar secara bersamaan dengan teman satu halaqoh. Sehingga santri yang akan ijin keluar harus menunggu temannya yang lebih dulu keluar

\footnotetext{
${ }^{30}$ Wawancara dengan Ustadz Muhaimin, selaku Kepala Biro Tahfizh Daarul Qur'an. Wawancara dilakukan pada 19 November 2016

${ }^{31}$ Wawancara dengan Ustadz Muhaimin, selaku Kepala Biro Tahfizh Daarul Qur'an. Wawancara dilakukan pada 19 November 2016
} 
halaqoh. (10)Guru wajib mengisi presensi santri di halaqoh.(11)Dalam hal setor hafalan baru, santri wajib setor minimal 7 baris. (12)Dalam hal muroja'ah hafalan baru, santri wajib setor muroja'ah hafalan baru kepada guru Tahfizhnya sebanyak 3 halaman.(13)Dalam hal muroja'ah hafalan lama, santri wajib setor muroja'ah hafalan lama kepada guru Tahfizhnya sebanyak 2 halaman.(14)Guru menuliskan nilai santri dalam Buku Catatan Tahunan Tahfizh (Dalil Sanawi). (15) Guru Tahfizh dapat melakukan moving class dengan memrhatikan efektivitas dan efisiensi, serta atas persetujuan kepala Tahfizh. (16) Guru Tahfizh diperkenankan untuk melakukan improvisasi dalam teknik pembelajaran dengan memerhatikan keadaan. (17) Guru Tahfizh bertanggung jawab dalam memastikan jalannya kegiatan Tahfizh di halaqohnya.

Adapun Sistem Administrasi Tahfizh Pelaksanaan Kegiatan Tahfizh di Pesantren Tahfizh Daarul Qur'an yaitu (1)Guru Tahfizh mengisi presensi (kehadiran) di kantor Tahfizh setiap kali jam Tahfizh (2)Guru Tahfizh mengisi absensi santri dan mengisi nilai dalil sanawi setiap jam halaqoh (3)Guru Tahfizh membuat surat rekomendasi tes kenaikan kelas untuk diserahkan ke koordinator Tahfizh (4)Guru Tahfizh merekap nilai dalil sanawi bulanan dan menentukan santri terbaik di halaqohnya (5)Guru mengikuti rapat evaluasi bulanan (6) Guru Tahfizh membimbing dan mengawasi tilawah 4 surat pilihan sesuai jadwal yang sudah ditentukan. (7) Mengajarkan teori tajwid praktis di sela - sela jam setoran. ${ }^{32}$

Dari pembahasan di atas, tampak upaya-upaya pembinaan tahfizh Alquran yang dilakukan oleh Pesantren Tahfizh Daarul Qur'an dalam tahapan proses pembelajaran tahfizh. Pertama, dimulai dengan Talqin, Tasmi, Murojaah, dan menyetorkan hafalan baru santri kepada guru tahfizhnya. Dalam pembelajaran tahfizh Alquran menggunakan buku Qoidah Nuroniyah yang berisi materi tentang belajar membaca Alquran dilengkapi Dalil Sanawi sebagai panduan dalam penilaian pembelajaran tahfizh yang dilakukan setiap halaqoh tahfizh. Kedua, perumusan ketentuan-ketentuan umum dan kedisiplinan dalam pelaksanaan tahfizh Alquran. Ketentuan kedisiplinan berisi kewajiban dan sangksi-sangksinya. Ketiga, petunjuk teknis pelaksanaan tahfizh Alquran yang perlu dipraktikkan oleh guru-guru dalam setiap

${ }^{32}$ Dokumentasi Tim Biro Tahfizh Daarul Qur'an, Panduan pelaksanaan kegiatan tahfizh al Qur'an Pesantren Tahfizh Daarul Qur'an 2015 
pembelajaran tahfizh yang berlangsung. Setiap guru diberi administrasi tahfizh yang perlu diisi mengenai pencapaian dan perkembangan santri-santri halaqoh tahfizhnya.

\section{Tahapan Penilaian Tahfizh Alquran}

Dalam melakukan evaluasi kegiatan Tahfizh Alquran, perlu dilakukan secara kontinu, objektif, dan dapat dipertanggung jawabkan. Penilaian dapat dilakukan baik dalam proses pembelajaran maupun setelah proses pembelajaran. Dengan sifat khusus yang terdapat dalam pembelajaran tahfizh, maka diperlukan pengaturan khusus pula dalam penilaiannya.

Penilaian tahfizh tidak hanya melihat pencapaian hafalan Alquran di akhir semester dengan mengadakan ujian tahfizh. Penilaian tahfizh dapat dilakukan pada setiap pembelajaran tahfizh yang berlangsung setiap harinya. Penilaian dalam setiap pertemuan tahfizh ini yang dipraktikkan di Pesantren Tahfizh Daarul Qur'an. Dengan menggunakan buku penilaian atau biasa disebut Dalil Sanawi. Penilaian tahfizh Alquran santri per harinya dapat dilakukan. Secara teknis, berkaitan dengan teknik evaluasi Tahfizh diberlakukan ketentuan sebagai berikut:

a. Kegiatan Tahfizh diberlakukan penilaian yang dilakukan setiap dilaksanakannya kegiatan Tahfizh.

b. Jika tasmi' ad-dars al-jadid (setor hafalan baru) sesuai dengan ketentuan (tidak ada kesalahan sedikitpun) maka diberi nilai 1 (satu), adapun jika terdapat kekeliruan dan atau kesalahan maka diberi nilai 0 (nol) dan harus mengulanginya di hari berikutnya.

c. Jika muroja'ah hafalan baru sesuai dengan ketentuan, maka diberi nilai 1 (satu), adapun jika terdapat kesalahan/kekeliruan lebih dari 1 (satu) kali, maka diberi nilai 0 (nol) dan harus mengulanginya di hari berikutnya.

d. Jika muroja'ah hafalan lama sesuai dengan ketentuan, maka diberi nilai 1 (satu), adapun jika terdapat kesalahan/kekeliruan lebih dari 3 (tiga) kali, maka diberi nilai 0 (nol) dan harus mengulanginya di hari berikutnya.

e. Jika selama mengikuti kegiatan Tahfizh (baik pagi maupun sore) santri menunjukan akhlak yang baik, maka diberi nilai 0,5 (setengah), dan jika sebaliknya diberi nilai 0 (nol). 
f. Jika selama mengikuti kegiatan Tahfizh (baik pagi maupun sore) santri disiplin, maka diberi nilai 0,5 (setengah), dan jika sebaliknya diberi nilai 0 (nol).

g. Dengan demikian, nilai maksimal santri dalam tiap hari adalah 4 (empat). Jika dalam satu bulan terdapat hari aktif sebanyak 25 hari, maka total nilai maksimal santri di bulan tersebut adalah 100 (seratus) dan dapat berkurang sesuai dengan keadaan masingmasing santri.

h. Santri yang memiliki nilai tertinggi dalam satu bulan, akan ditetapkan sebagai santri terbaik di bidang Tahfizh, dan kepadanya diberi reward sesuai dengan ketentuan.

i. Selainitu, penilaian juga dilakukan terhadap kelas (halaqoh) Tahfizh yang meliputi; kebersihan kelas, kerapihan kelas, keteraturan kelas, kedisiplinan (santri) kelas, keaktifan kelas, dan semangat belajar kelas. Kelas Tahfizh yang dinilai paling baik, ditetapkan sebagai kelas Tahfizh (halaqoh) terbaik, dan akan ditentukan setiap bulan. $^{33}$

Adapun teknis penilaiannya, guru tahfizh tinggal mengisikan nilai-nilai kedalam format yang telah disediakan dalam administrasi tahfizh Alquran. Berikut format penilaian tahfizh Alquran yang digunakan oleh Pesantren Tahfizh Daarul Qur'an;

Dari tabel. 1 penilaian di atas, jumlah nilai bisa menjadi gambaran pencapaian dan perkembangan tahfizh Alquran santri tersebut. Semakin tinggi nilai jumlah nilai yang diperoleh maka semakin baik hafalan Alquran bagi santri tersebut.

Bagi guru tahfizh sendiri cukup menuliskan di administrasi yang sudah disediakan. Hasil penilaian dari guru tahfizh kemudian diinput dan diolah oleh tim tahfizh yang sudah dibentuk penanggung jawabnya. Dengan format isian program Microsoft Excel maka pengolahan dan penyajian nilai-nilai tahfizh dari setiap guru tahfizh yang melaporkan nilai tahfizh santri halaqohnya dapat dengan mudah diketahui santri yang mendapatkan nilai tertinggi di atas nilai santrisantri lainnya dalam bidang tahfizh. Begitu juga dapat diketahui ratarata pencapaian santri per halaqoh guru tahfizh yang diamanahkannya. Dari data nilai ini pesantren merumuskan kebijakan dan upaya yang perlu dilakukan untuk meningkatkan pencapaian tahfizh Alquran.

${ }^{33}$ Dokumentasi Tim Biro Tahfizh Daarul Qur'an, Panduan pelaksanaan kegiatan tahfizh al Qur'an Pesantren Tahfizh Daarul Qur'an 2015. 
Dengan sistem penilaian tahfizh per pertemuan yang dilakukan oleh guru tahfizh kepada para santri menunjukkan Pesantren Tahfizh Daarul Qur'an senantiasa mengadakan pembinaan tahfizh Alquran yang intensif. Dengan adanya penilaian harian dapat menilai dan mengukur pembelajaran tahfizh yang berlangsung. Pembinaan tahfizh yang dilakukan pesantren dilakukan dengan dua sasaran, pembinaan kepada santri maupun kepada guru tahfizh sendiri.

Dalam mengevaluasi perkembangan program tahfizh Alquran, pesantren telah mengagendakan rapat dan evaluasi dua bulan sekali. Pembahasan rapat evaluasi yaitu kepala bidang tahfizh masingmasing unit yang ada di Daarul Qur'an melaporkan setiap pencapaian hafalan santri satu bulan ditujukan kepada biro Tahfizh. Dari laporan ini, Biro tahfizh Daarul Qur'an melihat perkembangan capaian hafalan santri masing-masing unitnya.
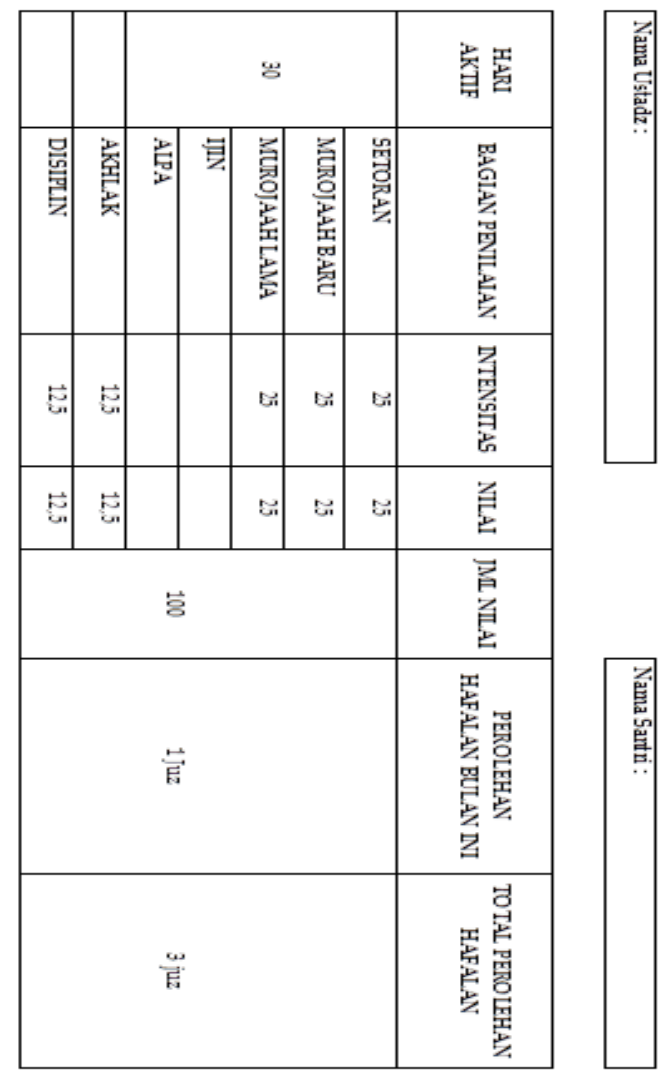

Tabel 1. Format Penilaian Tahfizh Alquran di Pesantren Tahfizh Daarul Qur'an 


\section{Penutup}

Pembinaan tahfizh Alquran di Pesantren Tahfizh Daarul Qur'an dengan mengintegrasikan pendidikan pesantren dan sekolah formal. Pendidikan pesantren memfokuskan pada program Tahfizh Alquran. Adapun Pembinaan Tahfizh Alquran di Pesantren Tahfizh Daarul Qur'an dilakukan dengan menyusun, melaksanakan dan mengevalusi program-program berkenaan tahfizh Alquran secara keseluruhan, sehingga pembinaan Tahfizhnya berlangsung secara sistematis, terencana dan terukur.terbagi menjadi tiga tahap yakni Pertama, Tahap penyusunan atntara lain (a)Penyeleksiaan guruguru tahfizh Alquran semakin sistematis dan ketat lagi. Diharapkan guru-guru yang mengajar Tahfizh memiliki kapabilitas dalam tahfizh dan mengajarkan Tahfizh Alquran kepada para santrinya. (b)Pelatihan pengajar tahfizh Alquran. Dalam rangka mengupgrade terus menerus kemampuan guru-guru Tahfizhnya. (c)Pembagian halaqoh Tahfizh dengan diberikan perangkat administrasi bagi guru tahfizh sebagai form penilaian tahfizh harian santri. Per halaqoh tahfizh diatur satu guru tahfizh dengan 15 santri sebagai anak didik binaannya dalam tahfizh. (d)Penyusunan dan sosialisasi ketentuanketentuan dalam menyelenggarakan pelaksanaan pembelajaran tahfizh Alquran. Kedua,Tahap Pelaksanaan yakni (a)Pembelajaran Tahfizh dengan sistem halaqoh dan klasikal. Pembagian halaqoh dengan mempertimbangkan kemampuan santri dalam Alquran sendiri. Pembagian halaqoh terdiri dari halaqoh Tahfizh dan tahsin Alquran. Halaqoh tahfizh bagi santri yang sudah lancar dan fasih membaca Alquran sedangkan halaqoh tahsin bagi santri yang belum lancar membaca Alquran dengan tajwidnya. Ada juga santri yang mengikuti tahfizh intensif dalam rangka pengambilan sanad hafalan Alqurannya. (b)Penggunaan Qoidah Nurroniyah dan Dalil Sanawi sebagai kitab panduan dan sistem pelaporan pencapaian hafalan santri per pertemuan pada jam Tahfizhnya. (c)Metode Tahfizh Alquran Pesantren Tahfizh Daarul Qur'an tidak mengembangkan metode sendiri. (d)Masing-masing guru tahfizh mempraktikkan petunjuk pelaksanaan kegiatan Tahfizh yang sudah dirumuskan Ketiga, Tahap Penilaian yakni Penilaian tahfizh dilakukan setiap pembelajaran tahfizh yang berlangsung setiap harinya. Dengan menggunakan buku penilaian atau biasa disebut Dalil Sanawi.Poin penilaian setor hafalan 
baru, murojaah hafalan baru, murojaah hafalan lama, akhlak yang baik, dan kedisiplinan santri mengikuti pembelajaran tahfidz setiap harinya serta penilaian dilakukan terhadap kelas (halaqoh) Tahfizh yang meliputi; kebersihan kelas, kerapihan kelas, keteraturan kelas, kedisiplinan (santri) kelas, keaktifan kelas, dan semangat belajar kelas. Kelas Tahfizh yang dinilai paling baik, ditetapkan sebagai kelas Tahfizh (halaqoh) terbaik, dan akan ditentukan setiap bulan.

\section{Pustaka Acuan}

Abbas, M. Ziyad, Metode Praktis MenghafalAlquran, Jakarta: Firdaus, 1993

As-Sirjani, Raghib, Cara Cerdas Hafal Alquran, Solo: Aqwam, 2013

Hasan bin Ahmad bin Hasan Hamam,Menghafal Alquran Itu Mudah, Jakarta: At-Tazkia, 2008

Hasni,Yasmina,Jumlah Penghafal Alquran Indonesia terbanyak di Dunia, sumber

Munawwir, A. Warson, Kamus al MunawwirArab - Indonesia, Surabaya: Pustaka Progresif, 1997

Nawabuddin, Abdulrab, Kaifa TahfadzulQur'an, terj. Bambang Saiful Ma'arif, TeknikMenghafalAlquran, Bandung: Sinar Baru Algesindo, 1996

Nurdin, Muslim, dkk, Moral dan KognisiIslam, Jawa Barat: Alfabeta, 2001

Sakho, Ahsin,Bimbingan Praktis MenghafalAlquran, Jakarta: Bumi Aksara, 2005

Soenarjo, Alquran dan Terjemahnya, Semarang: Toha Putra, 1989

Tim Litbang Daarul Qur'an, Panduan Kurikulum Pesantren Tahfizh Daarul Qur'an 2015 